\title{
Myths and Realities of Indian Monsoon (Onset and Rainfall) Forecasts
}

\section{S Jeevananda Reddy*}

Formerly Chief Technical Advisor - WMO/UN and Expert - FAO/UN and Fellow, Telangana Academy of Sciences [Founder Member] and Convenor, Forum for a Sustainable Environment, Hyderabad, Telangana, India

*Corresponding Author: S Jeevananda Reddy, Formerly Chief Technical Advisor - WMO/UN and Expert - FAO/UN and Fellow, Telangana Academy of Sciences [Founder Member] and Convenor, Forum for a Sustainable Environment, Hyderabad, Telangana, India.

In India the onset of the Southwest Monsoon Rainfall over Kerala Coast and its advance over the country is considered of great importance to the economy of the country as it involves the rainfall. The success or failure of crops, irrigation projects, hydroelectric power generation, drinking water supply, etc. in any given year is closely linked with the behaviour of the Southwest Monsoon Rainfall. Thus, everybody is anxious to know the date of onset of Southwest Monsoon over Kerala Coast and its progress and thus the quantum of rain with the start of warm summer month of May. India Meteorological Department (IMD) issues every year several types of weather forecasts. One such is long range Southwest Monsoon onset and rainfall forecasts.

\section{Onset of southwest monsoon}

The normal date of onset over Kerala Coast is 1st June. However, the variation in the date over the years in relation to the mean is very high. During 1921 to 1971 the earliest date was 13th May in 1967 and the delayed date was 16th June in 1932. That is, the difference between the two dates is 34 days. Here it is pertinent to note is, the dates of onset series showed a rhythmic pattern of 52 year cycle wherein 26 years present earlier than the average follows 26 years later than the average -- in majority of the years [around 1897E, 1923L,1949E, 1975L, 2001E, 2027L; E = early and $\mathrm{L}=$ late]. Stratospheric wind direction in May over Singapore also help on the onset, will it be early or late? Now IMD has modified the normal dates of onset over different met sub-divisions [I my self has presented them as back as 1975 based on the observed data series collected by me from IMD records and published in 2002].

The advance of monsoon over the entire country after setting in over Kerala follows a complicated way. There were years when the monsoon advanced over the entire country in a very short period of less than or equal to 20 days (1931, 1938, 1941, 1949, 1953, 1958 , etc.) as well as long period of more than or equal to 45 days $(1924,1943,1950,1952,1962,1963,1965,1967$, etc.). It is also seen in some years $(1933,1948,1969$, etc. $)$ that the advance took place rapidly up to some region and then slowed down considerably.
The normal date for Andhra Pradesh is 9th or 10th June. Over $50 \%$ of the years the monsoon advanced in to Andhra Pradesh within 10-days of setting in Kerala. It advanced in less than or equal to 2 days in years 1921, 1925, 1928, 1929, 1930, 1932, 1935, 1956, 1969, etc. In 1967 it took 31 days and it took more than 20 days in years 1952, 1957, 1959, 1960, 1965, 1967, etc. During 2019 the monsoon hit Kerala on 8th June, after a week delay. For 2020, IMD predicted monsoon is expected to hit Kerala Coast on the normal date of 1st June.

\section{Southwest monsoon rainfall}

The forecasts that help agricultural planning in advance are of paramount importance. One such forecast issued by the IMD is long-range rainfall forecast at all India level. Issue of such forecasts commenced even before Independence. Sir Gilbert Walker, a British Meteorologist formulated the basic concept of long-range rainfall forecasts. He was the Head of India Meteorological Service from 1904 to 1926, found associations between meteorological elements, such as rainfall and some other variables at an earlier time. Now, even private forecasters [for example SKYMET] also entered into this. However, individual forecasters are not referring their forecasts as $\%$ to a common normal or mean rainfall. In more recent years, emphasis has been placed more and more on understanding the scientific principles that determine the monsoon rain. Development of new observing techniques with the help of rockets, weather satellites and high altitude balloons provided to the meteorologists with a fund of new information. However, all these have not achieved much. It appears that sometimes the low tech is more powerful over the high tech.

Recently forecasters are using three factors in addition to several others [in early 70s I was associated with this division - IMD/ Pune], namely (a) Indian Ocean Dipole (IOD), ENSO and Meddan Julian Oscillation (MJO). IOD and ENSO remains over their respective positions, while MJO is a traversing phenomenon that propagates eastward. MJO associated convective anomalies at different longitudes influence sub-divisional rainfalls differently and thus it is less suitable as predictive parameter of Indian monsoon rainfall. 
In the Indian long range rainfall forecasts, commonly discussed/ used concept is Southern Oscillation cycle [SO/ENSO] related to instabilities in the tropical Pacific region -- Central Pacific warmer Sea Surface Temperature (SST) anomalies. This has warmer phase (El Nino) and colder phase (La Nina). During 1880 - 2006 of 126 years, only 18 years El Nino was present and in which 12 years the rainfall was below normal and only one year received excess rainfall; and in 24 years La Nina was present in which 17 years presented above normal rainfall. In 84 years no Southern Oscillation condition was present in which the rainfall was below the normal in 27 years and above the normal in 20 years. In all 49 years presented normal rainfall irrespective Southern Oscillation condition is either El Nino or La Nina or neutral.

IOD only pertains to the Indian Ocean. Scientists noted that the ENSO-induced anomalous circulation over the Indian region is either countered or supported by the IOD-induced anomalous meridional circulation cell, depending upon the phase and amplitude of the two major tropical phenomena in the Indo-Pacific sector. That is, an IOD can either aggravate or weaken the impact of ENSO on Indian monsoon. If there is a positive IOD, it can bring good rains to India despite of an El Nino year. However, from the above, it is clear that no such impact has been recorded in the past.

However, the forecasts are of statistical in nature and have no one to one scientific quantitative relation. So, for only in few years the forecasts were near to the observed value. The forecasts rarely predicted extreme rainfall events. This is basically because though the Southwest Monsoon rainfall following the 60-year cycle similar to Indian Astrological calendars [the current 60 year cycle started with Prbhava (1987-88) and will end with Akshaya (204647)]. The forecasts can be improved, for example the average of below the average 30-years can be used for years during 2017-18 to 2046-47; and the average of above the average 30-years can be used for years during 2047-48 to 2076-78 instead of present lump average. Currently IMD has the data for three above the average 30 years periods and two below the average 30 years periods - see below table for three such 30 years periods, 827.3 and $871.7 \mathrm{~mm}$. The same could be used in onset dates forecasts [here it is 52 year cycle].

IMD issues long range forecast in two stages, namely first in April and the 2nd in June. This forecast relates to overall Indian condition but regionally they are highly variable. Because of this, IMD started issuing regional level forecasts also. Indian rainfall forecasts drought assessment is dealt as follows: normal rainfall $=88 / 89 \mathrm{~cm}$ during June to September; deficit $=<90 \%$ of normal; below normal $=90-96 \%$ of normal; near normal $=96-104 \%$ of normal; above normal $=104-110 \%$ of normal; and excess $=>110 \%$ of normal.

\section{No barriers for drought}

The mean Southwest Monsoon rainfall for India is $85 \mathrm{~cm}$ [now IMD is using $88 / 89 \mathrm{~cm}$ ] with a coefficient of variation of $10 \%$. This is $78 \%$ of annual average. However, at Met Sub-division level these percentages are quite different. For example, for Coastal Andhra Met Sub-division they are 22\% and 52\% and for Telangana they are $23.5 \%$ and $80 \%$. Because of such variations in rainfall in almost all the years drought occurs over one part of the country or the other, with varying severities, namely mild (no crop loss), to severe (complete crop loss). Drought is highly misused word and as well complex phenomenon.

Because drought affects so many economic and social sectors, scores of definitions have been developed by a variety of disciplines. It occurs with varying frequencies in all regions of the globe; in all types of economic systems, socialist and capitalist; and in developed and less developed countries alike, the approaches taken to define drought also reflect regional differences as well as differences in ideological perspective, analyses. Rainfall presents natural variability or rhythmic pattern. The decadal average rainfall of all-India Southwest Monsoon presents a simple example. Here the rainfall presents 60-year cyclic pattern, see below.

\begin{tabular}{|l|c|c|c|c|c|}
\hline \multicolumn{6}{|c|}{ Decadal average of all-India Southwest Monsoon Rainfall, mm } \\
\hline Period & Rainfall & Period & Rainfall & Period & Rainfall \\
\hline $\mathbf{1 8 7 1 - 8 0}$ & $\mathbf{8 5 0 . 1}$ & $\mathbf{1 8 8 1 - 9 0}$ & $\mathbf{8 8 1 . 8}$ & $\mathbf{1 8 9 1 - 0 0}$ & $\mathbf{8 6 5 . 9}$ \\
\hline $1901-10$ & 822.7 & $1911-20$ & 821.7 & $1921-30$ & 837.6 \\
\hline $\mathbf{1 9 3 1 - 4 0}$ & $\mathbf{8 7 1 . 7}$ & $\mathbf{1 9 4 1 - 5 0}$ & $\mathbf{8 8 9 . 1}$ & $\mathbf{1 9 5 1 - 6 0}$ & $\mathbf{8 7 1 . 7}$ \\
\hline
\end{tabular}

Bold: Bell-Shape and non-bold: Inverted Bell-Shape.

Indian Southwest Monsoon season and annual rainfall at allIndia level, the above the average part of 30 years completed as $1987 / 88$ to $2016 / 17$. The below the average part of 30 years will be completing as $2017 / 18$ to $2046 / 47$.

The best way is crop early warning and drought monitoring through crop weather models at weekly or 10 day interval at location level. This I carried out for Mozambique [based on it presented food aid requirement at the end of the season] and Ethiopia.

\section{Assets from publication with us}

- Prompt Acknowledgement after receiving the article

- Thorough Double blinded peer review

- Rapid Publication

- Issue of Publication Certificate

- High visibility of your Published work

Website: www.actascientific.com/

Submit Article: www.actascientific.com/submission.php Email us: editor@actascientific.com

Contact us: +919182824667 